\title{
Comparative Analysis of Hyman P. Minsk Hypothesis to Evaluate the Current Credit Crunch
}

\author{
Jannatul Islam ${ }^{1}$ Md. Mehedi Hasan ${ }^{2}$ \\ ${ }^{1}$. Lecturer, Department of Business Administration, World University of Bangladesh \\ ${ }^{2}$. Lecturer, School of Business, Bangladesh University of Business \& Technology
}

\begin{abstract}
The research problem is topical issue named by credit crunch to the business and economic life in the society. All the businesses as an economic activities have ups and downs. But the phenomenon is changing with the phases of time. As a result the previous economist frameworks are getting inadequate to explain the financial crisis. The researcher takes the Hyman P. Minsky's framework as a justification tool of the current credit crunch. The research problem viewed in different way from the different point of view. The research presents interest and rationale in the introduction why the researcher selected the title. In the literature review the main theme along with the different authorities' scholarly work has presented for the justification and support the validity of Minsky's framework and his hypothesis. The literature review also covers some critics as well with prove of invalidity of the criticism. The methodology has written after that. Without the actual feature and difficulties of credit crunch it is not possible to argue about any conceptual validation. The reality and reason behind credit crunch have presented in findings and analysis showing the match of Minsky predictions. The discussions also covers the introduced of Minsky framework to the financial instability in short term and long term of the capitalist economy. In the conclusions and recommendation the researcher tries to show the economic trend and suggests the poli-psychological positiveness and international division of responsibility to create a positive eco-system to the society.
\end{abstract}

\section{Introduction}

This Study is on the recent issue of financial crisis. The great depression in 1932, the Russian housing bubble in 1998, the dot.com bubble at 2000 and the resent credit crunch are the outcomes of financial instability. The crises are coming with different phenomenon and in different region match with the phenomenon. When we see 12.5 millions unemployed in US, 3 millions unemployed in UK and Greece government is bankruptcy as not statistical biasness as a reality, we have to think about it how it possible. Has the economy stopped in those countries that are the authority of capitalism? Where the crisis comes from? Is it the result of economic corruption or income differences? Why the developed countries have hit by the resent crisis rather than the developing countries that have large amount of disposable income? Why the credit crunches happen?

To gain the idea about the research problem it is necessary to analyze the different view of different authority by keeping a main thought as a standard for justification its validity. The researcher of the study take the Hyman P Minsky's hypothesis as a base for the research as he thinks it is more appropriate to explain the current economic crisis. The different social, political and economic scientist viewed the crisis in different way.

The different view comes with different argument, definition and explanation about the research problem. Noam Chomsky (2006) analysed a fourth critical issue: continuous growing of democratic deficit, the mismatch between the public will and public policy. He claimed it as the sign of the increasing failure of formal democratic institutions to function. That's why the crisis is aroused in different socio-economic sectors. The Austrian business cycle theory, Ludwig von Mises (1912) argued the financial crisis is the result of ineffective central bank policies to keep interest too low for a long time. That central bank policy is causing excessive availability of credit for the borrowers speculates the booming period and decrease the household savings of future investment source.The ease credit leads to mal-investment, unsustainable boom and artificial stimulation. In this business cycle theory credit crunch is seen as a recurrection and reallocation of investment. A researcher of PIMCO, McCulley (1998) coined a term Minsky moment in which he clarified Minsky moment comes after a long period of prosperity and increasing values of investments, which has encouraged increasing amounts of speculation using borrowed money. He described Minsky moment is the point in a credit cycle or business cycle when investors have cash flow problems.

Credit crunch is an unsolved and critical issue. Though it is an economical term but it is mostly concerned with political, socio-cultural and psychological issues as well. So to identify the reasons behind credit crunch and its impacts we need to know the different aspect of related theories and research. Society can't be constant. On the phases of time it is changing with lifestyle, sourcing to survive, deal with problem, bargaining with other countries and international patrons. That's why today's economical problem named by credit crunch 
comes with different cause and effect. Though economical crisis is experienced by the globe and innovate new formula to retrieve, some sociologist argued it is the crisis of tradesmen's guilds that influence the state policy. They argued unemployment is the main source of financial crisis. Some of them analyzed it as a lack of disposable income for further investment. Some economist explained it as a fault of economic system which remains alive by the corrupted government. But the researcher found Hyman P Minsky is the most appropriate scholar who explained and made a framework very relevant to the current situation and predicting the future trend. His most relevant hypothesis is financial instability hypothesis $(\mathrm{FIH})$, and stability is unstable for the explanation of the process capitalism. He analysed and re-establishes the economic cycle in short run. He focused on long term trend of capitalism as well. Minsky explained the short term and the long term process and trend of economy systematically with an advance sense that's why the researcher became interested to his framework as a research topic.

\section{I.I Objective of the Study}

The objectives of the research are as follows:

- To show the reason behind socio-economical crisis from the analysis of Minsky.

- To evaluate different views about these economical crises.

- To find out how the policy maker and financial institution is responsible for credit crunch.

\section{I.II Limitations of study}

The research problem is too large. As a result it is impossible to identify every issue and going through all the framework of Minsky. The research is on finance. The study is not going to a lot for the finance and mathematical analysis. For the simplicity and others limitation, it is trying to present the conceptual framework of Minsky and his followers to justify the validity for explaining the resent financial crisis.

The research problem is a combined issue of a lot of factors. So there are must some limitation to find the actual data in niche scope of area. The vital limitation of the research is lack of survey. It is already mentioned above that within the short time period it will be hotspots or one kind of hierocracy to satisfy the research objectives.

The researcher also acknowledges the inadequate skill and expertise to do a quality research in a complex field with no previous experiences. As the research is an area of finance, it needs some mathematical and statistical calculation. It is also not conveying by the research satisfactorily because of researcher lack of technical knowledge

\section{Literature Review}

The proposed research issue is very topical and has a great value in the context of human society. The problem is old as well as very new. The economy is the basic of a nation. So if the civilization exist the issue of the research will remain be the valuable. Though lot of studies and research has been done on this topic, still it is unsolved issue. It is not a new problem but present recession is too deep which could stay long and affect all over the world in a large scale. Some people have the different argument compare to other about causes and remedies. Though there are different argument about the above research problem it is commonly acknowledged that credit crunch bring recession and economical depression. All the problems happened from credit crunch and its causes might view in different perspectives. But the solutions of credit crunch are more complex. The literature review aims to evaluate the current financial crises by revisiting Hyman Minsky's financial instability hypothesis (FIH) (Minsky 1982 and 1986) comparing to other's existing theory. The authors of the research have the interest to go in depth of Minsky's advance sensed of shifting of capitalism in a new era of managerial capitalism to money manager capitalism. But it will be discussed in detail to the main report.

Charles J. Whalen (2008) cited that Minsky is one of most famous foremost American economist and researcher on financial crisis and economic instability of capitalism and still now his ideas is valid and appropriate to analyse and understand the resent financial problem and economic meltdown. The most usual word now a day is Minsky Moment coined by McCully in 1998. Minsky moment comes when the lenders are much cautious and restrictive to finance. He is famous for his great idea of 'stability is unstable'. The current economic crisis is so deep. Economist Langfitt (2007) responded it in a National public radio and said it is digester and too much worse than anticipated by anybody else and he is shocked.

Demian Perry (2009) said Minsky Moment as a third horseman. According to him the existing economic theory 'the market efficient' and can predict and model by flip a coin and the market irrational theory is domination last decade became failed to predict and match with the current financial crises. Now the most suitable model is financial instability theory (FIH) and Minsky Moment concerning the housing bubble and financial institutions.

The theory is modelled by three criteria combination of hedge, speculative and ponzi. The Minsky has re-established the cycle of economy in different way. Mainstream economics in general views capitalism as a 
stable and steady. If any crisis arises, it could arise from preventive policy maker's mistakes or by the external forces. But Minsky contrasting it argued that the phenomenon of capitalism and the way how it work is responsible to create crisis within. Always there are argument around and some criticisms about Minsky hypothesis as well. The critics depicted (FIH) not yet a full-fledged theory. Still now it is lack of some crucial variables and specification. For this reason Tobin (1989) accused his theory as an "implicit theorizing". But at current situation most of the economist are analysing and discussing the crisis in the perspective of Hyman Minsky model and policy maker's are following the recommendations of Minsky, though Mitchel Y. Abolafia(2009) cited, 'Keynes' famous observation that policy makers 'are often the slaves of some defunct economist."”

The reasons behind credit crunch are numerous but it is obvious that credit crunch bring the recession. The financial crisis changes the previous scenario and relations of interest rate and the credit. Basically lenders and investors always are looking for the least risk of their money which compromise the lending quality and accompanied with unexpected outcomes. Charles J. Whalen (2008) described three dimensions liable for present credit crunch. 1) Corporate buyout. 2) Commercial paper. 3) Hedge fund. According to him previously bank was eager to lend for buyout firms. The point was banker had the facility and opportunity of reselling the loan to others. When portfolios investors see themselves in trouble of inability to resale their loans and losing big amount then buyout deals sat idle. The reason is rest of the investors already got the information and become cautious not to be caught by the bad situation experienced by others. In the second dimension commercial paper for securitization had used for loan and mortgages was dried up like buyout loans. Another important which can called third dimension is hedge fund. It was unconventional; operate in secrecy and for wealthy individuals. Adam smith (1776) had criticized tradesman as they acting together within the guilds and speculate the market. The hedge fund was mostly relied on commercial paper and used for mortgages. When it became clear the borrowers could not fulfil their mortgage obligation then the flow of hedge fund dried up. The entire dimension comes with a result which is called "Minsky moment" by the researcher and economist. The Minsky moment is a situation of economy coined by McCully when he done a research in 1998 on Russian financial crisis (Lahart 2007). Further George Magnus (2007) explained it more detail. According to the stage is start with rapidly increasing debt availability with the phenomenon of replacing traditional borrowing replaced by new debt and borrowing for repay the existing loans. After a period of time the lender and investors become worried and anxious and try to be more safe, conservative and restrictive to secure the money which bring the Minsky moment. McCulley, quoted by Lahart (2007) depicted when the Minsky moment keep unchecked it can become "Minsky meltdown" and produce economic recession. Hyman P Minsky used to call himself as a Keynesian. He was the assistant of Alvin Hansen to university of Harvard who was known as a leading Keynes discipline (Whalen, 2008). The two fundamentally distinct views are dominating the market economy. One is smithian view and another is Keynesian views. Ferri and Minsky (1992) explained both of the views. In smithian views they found business cycle is a product of exogenous shocks. Mainly the shocks come from external forces. The most influential force in smithian views is unanticipated public policy. In this view is called as "real business cycle theory" in which believed in full employment during all stages of business cycle. In another view of Keynesian business cycle it is believed that boom and busts, ups and downs are the internal dynamics of market. The Keynesian perspective is, instability is the genuine social problem and it is associated with the increasing of involuntary unemployment. Both of the view previously dominated the market economy proved as inadequate in last few recession periods. Minsky interpret the market economy and business in 1975 in alternative way and establish a new hypothesis called by financial instability hypothesis (FIH) and wrote a book named by John Maynard Keynes. It is the basic and new contribution to economy differentiates him from the mainstream economics calling by post-Keynesian economics. According to Demian Perry (2009), the current market hypothesis is "market is efficient" and can be predicted. In this hypothesis it is believed that even individual decision is wrong about the portfolio value it can't go so long as the whole market force and back it to the right track. It's a smithian view in which it is viewed that the financial activities are managed and driven by an invisible hand. Another one hypothesis is price and value is irrational. The market is driven by masspsychology, changes in stock price, over react to new information. But Minsky argued the instability is comes from the process of capitalism itself. According to his (FIH) theory, the economy and the financial structure of capitalism become fragile in the way of its growth and prosperity. Where it is highly profitable areas, enterprises are taking more amounts loan as a debt to invest and the scenario is followed by others as they see and think it is opportunistic way of success and profit making. Increased in profit margin encourage to go for more debt by making easy access to the loans which might go outstanding (Minsky, 1975). He said it as an evolutionary tendency. Minsky (1989) wrote primarily in the year of 1960s about his famous framework of financial instability hypothesis. Later in the year of 1964 he modelled it with three hypotheses. Firstly, the characteristics and behaviour of the real variables depend on the structure of the financial system. Secondly the financial fragility and crisis is likely to depend on financial structure of the economic process which preserve the 
reflection of the past history and the trend of the economy. Thirdly the economic situation and the financial structure gets continuously increase in the instability with the boom proceeds.

All the process might convey the mass psychology. Nobody wants to keep behind in case of less investment. The similar institutions feel inferior. The borrowers are following the same way of mass hysteria. The competitiveness and less risky investment also fuel this process. Primarily Minsky explained in his FIH hypothesis that realized profit is determined by investment and expected profit required investment in future. As a result liabilities are upon investment. The financial hypothesis is based on the total debt and its impact in a economic system. In this theory he considered the banking system like an economic activity looking for profit and the banker are same to be like other entrepreneurs in capitalism who innovate new instrument to ensure profit. Minsky (1986) in the expansion of his hypothesis of (FIH) the aspect had described according to the stages of economy in book named "stabilizing an unstable economy". He showed the financial stages moving in consecutively first hedge finance than speculative finance and in the final stage to the critical situation of ponzi finance.

He explained hedge financial stage; borrowers got the ability to pay back the outstanding interest and principal according to the loan obligation. In this case, there's nothing to do with hedge fund. In the second situation called by Minsky the speculative case, in this situation the economy doesn't face the criticalities to much but the lender and investors need to be careful. They need to carefully treat the case of lending because in this stage the borrowers only are able to pay the interest and the principal remain unpaid because of inability to repay. As a result they have to have rolling on further financing. In case of the ponzi finance, the borrower's can't pay back the interest or the principal. They have to borrow more and more money only to pay the interest (Minsky, 1982\&1986). He described ponzi finances as the critical point where margin of safety become lower and the holders fall in deep debt. He argued bank as hedge economic unit of finance. He further said that if hedge finance dominates the market then it well and we can say it as equilibrium and when speculative and ponzi finance is greater than hedge finance then it is a sign of downturn and the market is disequilibrium.

He also gave much emphasis in his hypothesis on lending as an innovative and profit-driven business. Minsky (1992) depicted that the banker, financial institution, middleman and agent in the financial system are the merchant of debt. They always try to innovate financial instrument regarding the assets they have and acquire and the liabilities they sale and market. His explanation of evolutionary tendency and drive to innovation are most appropriate to the current financial fragility or known as credit crunch. Some example of innovation in lending are CDO, CDS, CDX, special purpose vehicle, equity tranche, super senior tranche, regulatory and ratings arbitrage, teaser rates, no-documentation mortgages, piggyback mortgages and NINJA (quoted by Markus, 2008). All the lending innovation fuel the investment in lending and following the evolutionary tendency comes to the ponzi finance where the borrower can't pay back the interest and principal at all. They are going to be more depended on debt to keep with the loan obligation and scared of bankruptcy. When the lender becomes sure that the borrower's can't pay back and the investor's are going to lose. The whole scenario changes at a time. The funding becomes shrunk. Loan obligation and requirement become too strict than before. The evolutionary sectors fall, which is termed Minsky moment by Paul McCulley in 1998. The housing boom is appropriate example of this explanation which is liable for the present credit crunch.

Minsky said in 1982 that as acceptable liabilities structure is subjective profiled company has to force for selling its assets when it is shortfall of cash. According to his argument, when anything goes wrong it could be sudden. Christopher Huhne (2007) an MP in British parliament and an economist quoted by Whalen (2008) t said, "Financial markets fall in love with new things, with innovations. It is very difficult to assess the real risk of them because you don't have a history by definition". With the phases of time the scenarios change. The banker and lender what Minsky said innovate new financial instrument to cope with the situation and avoiding difficulties aroused. Minsky explained further in the year of 1992 by disagreeing the mainstream economic theory that capitalism doesn't necessarily rely and depend upon the exogenous shocks by external environment to create the business cycle. It's a kind of influence and affection of debt on economic agent's phenomenon and system behaviour. Its built-in and obvious in the period in a specific business. He suggested when the business cycle reach to the so called Minsky moment the collective action is essential. He mostly emphasises on central bank initiatives. In the current scenario, we see the central bank initiative to handle to situation. The bank of England declared the historical lowest rate of interest at .5p (telegraph.co.uk). As a collective action we see the London summit 2009. Most of the prominent country sit together and tried to act collaboratively to cope with the credit crunch. They have declared $\$ 1.1$ trillion package programme for restoring the growth and job and get back the confidence of financial sector (London summit 2009).

Some of the critics see Minsky's hypothesis is appropriate to a single economic unit (Whalen, 2009). But the view of economic fragility over a period of prosperity was an empirical evident in 1990s of high-tech boom and in housing sector during the early and mid2000s. The insight of Minsky hypothesis though indicated to the financial institution, the prime economic unit influences other like household and other business units in case of availability in finance. Though the (FIH) is experienced before, why it comes again? Dymski and Pollin 
(1992) depicted that nobody likes to be left behind for underinvestment in a booming sector even though they have full knowledge of the Minsky model and the financial crises will rise at some point. They analysed in the same time aggressive firm and bank loan officers get reward for pursuing profitable opportunities and competitive advantages. Minsky said it is a cyclical path of economy which comes with new financial innovation. In 1990 criticizing the innovation of securitization, he said claimed "which can be securitized, will be securitized". Der Hovanesian (2006) criticized that securitization of mortgages steer customers with less concerned about the creditworthiness, toward the most profitable types of mortgages, even they were the riskiest. Minsky (1990) analysed money manager capitalism is international. Further in 1995 he discussed that the problem of finance whether the institutions is national can contain the result of global financial fragility. The present financial crises proved the relevance of Minsky hypothesis which started with housing boom fuelled by rising expectations. The boom sector comes with expanding debt and financial innovations. In the prosperity the bubble burst and credit crunch occurred which turned into banking and stock market crises and finally the recession. Though statistics does not deserve the whole insight but can show the feature. The current recession how deep can be felt little bit by knowing the 12.5 million unemployed only in U.S (discusseconomics.com, June 03 2009), the number of unemployed in UK hits by 2.47(dailyrecord.co.uk, Sep 16 2009) and globally only in financial sectors around 350,000 jobs anticipated to go (themoneystop.co.uk, Jan 5, 2009). But how much difficulties lies ahead nobody knows. Buffet (2008) explained as "you only learn who has been swimming naked when the tide goes out". But how it comes through? Minsky said it cycle of capitalism. Stephen Lendman (824-7) described that Minsky developed seven stages to show how the capitalism work. The stages are given below:

\section{Stage-1: displacement}

In this stage investor perceptions changed and market disruptions happened due to different types of disturbances. The disturbances may come from housing bubble, credit squeeze, sub prime mortgages and so on.

\section{Stage-2: price start to rise}

From the displacement markets are going to up with price rising due to fundamental improve. Lender and investors begin to notice that it's the time to gain.

\section{Stage-3: easy credit}

The fundamental improvement needs help and easy credit. When the conditions improved due to the supportive tools it fuels to speculative finance and more investors jump to borrow to buy new home or other consumer spending.

\section{Stage-4: overtrading}

As profit making easier, the investment happened with foolish behaviour. With the trade rise, the shortages in cash flow emerge and output comes with overtrading.

\section{Stage-5: euphoria}

It is the most risky stage. The cautious manager and investors become worried about the situation. But the agency and fraudsters still claiming the time got opportunities and market have a long way to go. Stage-6:

\section{Stage-6: insider profit taking}

The history repeats again. Everybody can feel the things gone too far to control as they previously thought can get out of it.

\section{Stage-7: revulsion}

The euphoria can turn into revulsion very quick. The reason is downward momentum is the faster than the heading up. In this stage market got panic with unexpected and bad news. Market become infected by mass psychology and humour which makes the investors force sell. The finance becomes dried-up. Cheap credit got ends. The Minsky moment comes up.

Charles J Whalen, a Minsky analyst and sometimes worked together tried to find for some remedies of Minsky moment. They emphasised on two types of economic policy; recovery and reform. Minsky and Whalen (1996-1997) suggested that to stabilize the financial sector and preventing the downturn and becoming more severe, the policy objectives should be macroeconomic stability and shared prosperity with abroad. For recovery he raise three components must have to consider for the government policies. He argued about fiscal policy, monetary policy and financial market policy to be the most responsible tools for recovery. He termed it as a 'big government' in 1986 in his article stabilizing an unstable economy. He described it as surpluses in inflationary period to cover in deflationary period. He further argued in 1986 countercyclical spending should be 'built-in' 
but he recognised the discretionary action would be needed. Minsky (1986) emphasised on central bank and recognised as responsible for containing and offsetting financial instability Mnsky also proposed for financial market policy to get recovery which is followed by bail-out and the troubled asset relief program. But the bailout and relief program is not working very well as bank and financial institutions reluctant to further lend instead of transforming the liquidity to stock dividends and other issues. The latest plan of 'public-private partnership' is comes out. Stiglitz (2009) called it 'win-win-lose' situation in where banks win investors win but taxpayers lose. In this case Minsky preferred President Franklin d. Roosevelt strategy of sorting out. He argued for bank restructuring by closed insolvent banks and assisting solvent. But critics said it's a great weakness of Minsky argument as he didn't define the actual situation to consider taking the decision and his three stage of finance (hedge, speculative, ponzi) can't show the actual scenario (Bernanke 1983; Benston and Kaufman 1995).

So it deserves some more specifications. But Krugman, dean baker and k. Galbraith all the authors (2009) call for the similar action proposed by Minsky before. Minsky also suggested for reform. The reforms agenda must required the stricter regulation and supervision with national commitment and promote international economic stability for the financial system. He said it a 'never-ending struggle' of financial system in financial market. Currently all the financial policy more or less following the Minsky perspective by getting transparency of industry, rigorous bank examinations, use of ARMs as a regulatory instrument. The new innovated finance got lot of scrutiny by financial system regulator. Stuart Calder (2008), described and suggests the following initiatives to shape the investment in the right direction;

- Tick by tick historical price documentations by a vast arrays of data in a massive and accessible computing power.

- Virtually investment system in any asset through a process of liquidity convergence globally by super exchange policy of 24 hours a day.

- All time access to the computing power and data through the high bandwidth connection from a super powerful portable device.

- The increasingly use of artificial and programmed intelligence for the individual and collective investor as a part of whole investment management process.

Minsky's new perspective of money manager capitalism (since 1982) employers are moving to treat labour as a commodity (Minsky and Whalen, 1996-1997) which is very relevant with the Marxism. Marshall, Glover and king in 2010 argued that nation have to emphasis on growth of domestic jobs with family supporting wages and have the access to the education and training required for the jobs. The also suggested to find out the way of workers-managers partnership. Minsky (1995) had suggested for global coalition to enhance labour rights and promote job growth. But world's key policymakers are tending to be reluctant to follow the direction. The author of the research is interested to discuss it in main report and find out some more of the crises between 'managerial capitalism' and 'money manger capitalism'.

\section{Methodology}

The research topic is very topical in the field of economy and political process. Though the money is nothing except the medium of exchange and created out of debt, it is the blood of society. It doesn't matter how much it is, the matter is how one can manage it. Hyman P Minsky found it and recognised it as a change of era from managerial capitalism to money manger capitalism. As the topic is about credit crunch, it is so broad and covers a vast area of micro and macro level including social system, political view, psychology, economic process, demographic phenomenon, natural assets, historical background and production system. Again in specific area there are also lot of hypothesis and so many scholarly works. So it is also will be foolish of lost around it. That's why the study is trying to focus on Hyman P Minsky's hypothesis of financial instability hypothesis (FIH). Because he is the most recognised scholar of America and his work is studying in different countries recognising more relevant in economy. The research deserves deductive method. But it is going to produce some new conceptual argument as well. It is trying to find out the generalize valuation. Because the people who directly affected and involve with the situation is more important than studying thousand pages. The scope of research also covers different types of secondary data like as; journal, books, newspapers, expert's articles different economic theories and reviews to support the research aims. The research is conducting through both of qualitative and quantitative methods. Research is going to cover the mass perception about the research problem form different survey and scholarly works already done on it. The causes in details, historical phenomenon, ingredient of problems, information and feature of problems, Sectoral sufferings has gathered to understand the actual situation. All the included causes and features are very relevant with the research aim as it is focused on relevancy of Minsky's hypothesis. The information has gathered mostly from US, UK and others developed countries. The reason is convenient data are available in those countries. The other reason is, those countries are most affected as others developing countries have adequate disposable income. Also it is essential 
to narrow the area as well and find the countries suffering from similar difficulties to fulfil the research aim in limited timeframe with limited resources and other limitations.

The notes and references of scholarly work have collected from the focused scholar Hyman P Minsky itself, from his fellow and the scholars written upon his work by explaining or criticising. The researcher mostly has preferred the review papers on Minsky works. The theoretical framework of the mentioned scholar hypothesis could be measured by explanation and data available from different kind of research and responsible institution more empirical. It's also a reason to give more concentration on secondary data and linking the concept rather than going for field work. The main source of secondary data is reliable and authentic internet sources. As the issue is very old as well as empirically new all the time, the study has some information and ideas from daily newspapers and articles which is not much quoted. The methodology also affected by the observation of social crisis and political situations. That's the main interest of the research to convey. The validity of authenticity is up to the time and situation. The sense of humour and feelings of socialisation is also important which coming up as an authentic and prove invalid the old one. The titled scholar also recognised as an economist out of mainstream. As the study has mentioned earlier with a vast area, it is tough to gather only satisfactory data from a specific area. Most of the information is developed country based like EU, UK and US. But the matter is the current criticalities are facing by these countries a lot. And most of the research on this research problem is done by these countries. So for the availability of data and scholarly work those countries came first. The study tries to find the relevancy of Minsky's hypothesis in the current financial crisis not to oppose this hypothesis as primarily he values it as valid to justify positively.

\section{Findings \&Discussion \\ IV.I Causes and background of credit crunch and current financial meltdown}

The recent financial crisis is recognised by the economist as the worst than any time except the great depression in 1930. Though the research main aim is to see and discuss the current financial crisis in the perspective of Hyman Minsky hypothesis what was done before in another financial crisis, it has a responsibility for comparative analysis with other views in the field. From the overall point of view the study find out some point as causes of credit crunch which are going to discuss below.

\section{i) The rapid growth in the housing price well known as a housing bubble}

The rapid increase in housing price considered as the most liable factor to the current financial crises. It is most usual word in $1^{\text {st }}$ world countries who are suffering from credit crunch and financial downturn. Economist and researcher often called it Minsky moment which is theorised by Hyman Minsky and the term is coined by McCulley when he done a research in 1998 on Russian recession.

\section{ii) Easy credit conditions and low interest rate}

It's more or less a mass psychology as nobody want to left behind because of less investment when the opportunity is seems to be available. Lower interest rate and easy condition makes borrower more eager to finance. It is roger w. garrison (1997) who figured out how easy credit and low interest rate is liable for credit crunch

\section{iii) Sub-prime lending}

Sub-prime lending is happened when loan is available for potentially defaulter. When a borrower with weakened credit history can get credit knowing it might get unpaid is called sub-prime lending. Minsky described the economic cycle work as like follows: Hedge fund $\rightarrow$ speculative fund $\rightarrow$ ponzi finance.

\section{iv) Predatory lending}

Predatory lending occurs in so many ways. This type of practices mainly takes place in long term like mortgage lending and short term basis. In terms of long term predatory lending practices the common scenarios are excessive fees and other prepayment penalties, yield spread premiums, loan flipping, selling extra product like insurance, mandatory arbitration, steering customer to sub prime loan etc. in case of short term predatory lending we see the common features are payday loan, overdraft loans, car title high rate loans, tax refund anticipation loans. All the above mentioned practices of predatory lending make the market as a sub prime. As a result imperfection and in consistency take place in the market efficiency.

\section{v) Deregulation}

From the early 1980s and 1990s the banking sectors rising a lot. As a result the activities and range of product diversification became higher than before. In the phases of time regulatory framework could not keep pace. The future of financial sectors became complex and unpredictable. New financial innovation happen and important of shadow banking system become higher. Off balance sheet financing is the most destructive tools of 
deregulations. Warren Buffett (2003) referred deregulation weakness is a prime cause of financial instability. He claimed the deregulation as a financial weapon of mass destruction.

\section{vi) Debt burden along with the over leveraging ratio of the financial institutions}

Because of ponzi finance financial sector is burdened by increased debt and over leveraging happened. The level change in the margin of safety. The margin of safety set to the lower than standard. When the above scenario is appeared the forced sale is occurred and financial institutions become unable to finance which is a great reason of current financial crisis.

\section{vii) Financial innovation and complexity}

Financial products development is an ongoing process to fulfil customer's objectives which is termed by financial innovation. It brings complexity when existing regulatory body can't cope with the situation. Hyman Minsky (1992) also mentioned it very strongly as liable factors to the financial fragility. Some examples of financial innovations are the mortgage backed securities (MBS), collateralized debt obligations (CDO) and credit default swaps (CDS). Christopher Huhne (2007) an MP of Britain and an economist quoted by Whalen (2008) said, "Financial markets fall in love with new things, with innovations. It is very difficult to assess the real risk of them because you don't have a history by definition".

\section{viii) Unproductive ups and downs of the shadow banking system}

Shadow banking system runs as a parallel banking system with little regulatory control. Because the regulatory body can't keep pace with shadow banking system and its new financial innovations. The President of New York federal reserve bank Timothy Geithner (2008) in his one of speech, blamed shadow banking system for freezing of credit markets. He analysed how the shadow banking system plays an influential role to the economy and collapse very quick and destroy the financial market. Mortgage securitizations CDO and credit default swaps (CDS) has proved the most destructive weapons to the economy. The shadow banking system has played rival and sometimes unfair lending practices. As a result it was difficult to forecast future of financial market which is also liable for current credit crunch.

\section{ix) Commodity bubble}

People want commodity to survive not the money. As a result money itself got no value except as medium of transaction. That's why when money is more available than before the demand for goods and services going up in terms of money. Commodity price also can be high because of scarcity and availability of commodity to fill up the demand. As the money supply was high in the way of sub prime lending, ponzi finance and easy credit condition the commodity bubble comes up.

\section{x) Systemic crisis}

Credit crunch is a systemic crisis of capitalism. The more money comes in the market the more debt create and one typical people become credit worthless. It is the cyclical process of capitalism boom and bust. The capitalism makes class deviation among the people. The GDP may go up in paper but in terms of money inflation the overall economy going down day by day. Unemployment becomes higher.

\section{xi) Role of economic forecasting}

The role of economist in economic forecasting is mysterious. Critics argued they might blind to some sort of category or biased to capitalist ultimate goals. As a result the economist and policymakers couldn't predict the economic downturn which also liable for the quick falls of economy. In the other hand the economic trend and activities become more and more critical with the new financial innovation and deregulation. What Minsky called the changes of era comes with different phenomenon. As a result the previous framework and hypothesis didn't work properly in resent situation.

\section{xii) Declines in bank capital}

The bank does business with the money of others. In the process of modern banking system and money circulation process the money become 99 times rather than the real. The process stops when the credit remains unpaid. The bank capital sharply decline as the modern banking system doesn't work because the money circulation stopped. Clair and Paula (1993) explained that effects of business cycle don't cause a credit crunch solely. Lending is most important. In the slow and downturn period demand of credit decline and the supply of credit also decline for many reason. Losses of loan come with the result of reduction in bank capital. Sometimes desired safely level, provision by regulatory body risk based capital ratios and other provisions reduce the bank capital to lend. 


\section{xiii) The modern banking system and money circulation}

The modern banking system and money mechanism process is also liable for the financial instability.. In the modern banking system and the way of money circulation the money can be 99 times more than the actual. It becomes critical when the lent money remain unpaid. As the supply of money become too high in money circulation process than the real money when the money get unpaid by the borrowers the actuality takes place. The bank can't go with there own process and become stuck. They have to change more IOUs but obviously in certain level. So the modern banking system and money circulation process is also liable for the financial crisis.

\section{xiv) Resolution of authority to fail depository institutions}

The losses of loan lent to the borrowers stopped the money circulation process and directly influence to the decline of capital. Reduction in the amount of capital causes demand of further capital. When a depository institution becomes loser the deposit insurer are taking over the capital. Normally the insurer cleans up the portfolio of nonperforming assets and than go for sells the failed institution. It is only can be acquired by the other company who have excess capital of its regulatory minimums to increase the assets and hold it. Not only the failed bank but also the undercapitalized bank also clean up there non performing portfolio to increase leverage ratio.

\section{xv) Bank supervision overreaction}

Bank supervisory overreaction and regulations also a constraint in credit availability. The safety rules and guidelines for bank lending are sometimes too far to get the loan. Some of the supervisory roles affecting bank lending can be like as follows:

1. Criticizing the loan already approved and exist and requiring loss provision of loan along with charge offs.

2. Conservative evaluation of bank's wealth and condition for more leveraged.

3. Criticism could discourage loan extension.

4. For weak and troubled institution may restrict lending directly.

5. Lots of loan documentations and regulatory burden.

6. Overreaction changes the perceptions of loan performing manager.

\section{xvi) New credit standards set by bankers}

When recession occurred the bankers change their risk-taking behaviour. Lender willingness to lend is reduced. Bank want to be sure about there safety margin and sufficient capital to protect themselves when loan loss happen. In terms of economic downturn the bankers raise their lending standard and deny lending to many of borrowers who might be qualified for credit previously. The changes in standard change the status of borrowers from creditworthy to credit unworthy and its damage their businesses which cause another reason of recession.

\section{xvii) Regulatory burden}

Banking sector is most critical sector now a day. It is most regulated as it is seems to think most liable for the current credit crunch. Banks need to employ more people to comply with regulations. Bankers have to focus on upcoming regulation which might is out of the article and obviously it incurred a hidden cost. The regulations impose more cost on banks and cause higher costs on lending than in investing. Regulatory burden on lending is more which discouraged banker in lending.

\section{xviii) The increased legal liability of lender}

The legal liability of the lenders is a matter of going concern on the banker. The most critical problems for the banker are uncertain circumstance. It is very difficult to take legal action when the circumstances and liabilities are not previously measured. Uncertainty reduces the lending as it is unable to expose to lawsuits. The most concerning area is environmental clean up cost for property recover from borrowers. The properties contamination cleanup expenses also reduce the banker's eagerness of lending in those sectors. Bank can be sued for excessive control or wrongfully termination of loan. Banks have limited legal power to take action for repayment and protect their collateral. Sometimes they have to owe the cost of defending sue mentioned above. As a result bankers are more concerned and discouraged in lending.

\section{IV.II Principles of Minsky analysis}

Obviously Hyman Minsky is known as a capitalist economist. His work was on basically to find out the phenomenon of financial instability. Though he said himself as a Keynesian, his work and theoretical framework considered as new and unique hypothesis out of the arena of mainstream economist. His principles 
of the framework were reviewed by Eric Tymoigne in June 2006 in working paper 452. According to the analysis and other supportive and supplementary papers Minsky's principles of the framework are given below;

\section{i. Capitalism is a monetary production economy}

Minsky's main attention was in capitalism. He recognized different forms of capitalist society with the similar characteristics. According to him (1983), the capitalism works in an integrated production system. He analysed in capitalism the trade and wealth owning happen in a financial structure of claims and commitment. He depicted the system works in a world of reality within the irreversible time. He clarified capitalist economy as a monetary production economy. He described it like; money is not only usual tools in capitalist society but also is the centre of all decision making from the beginning and end of the economic process. The artificial and invisible frame in financial structure is an important part in the system of capitalism. In this system normally the nominal value is more than the real value. Minsky claimed it as the prime reason to the instability and flexibility in long run for the capitalist economic process. Minsky analysed in 1986 that in the complex financial system the capitalism causes the unemployment and imbalance in the income level along with the inflation and financial instability. He also explained the financial mismatch which is created out of financing in production, acquisition and others economic activities and appears a maturity mismatch. He claimed that the phenomenon of financial mismatch is a fundamental flaw of the capitalism.

\section{ii. Agents behaviour}

Minsky includes agents as vital part of capitalism that makes arbitrages among all assets of productive and financial. They work as a useful part of competition and seeking profit and capital gains from the rate of return (Minsky 1975, 1986). In Minsky studies financial decision based on conventional judgments. Individuals construct mental model in which process they perceive the present situation of the economy how it working and in the future how it will be working. In this case Minsky argued there's nothing to do with it. That's why in his analysis conventions plays a central role. According to him decision making always consensus and certainly equivalent which is depend on bankers mood, own liabilities and regulatory bodies criteria. In this case the borrowers must meet the loan criteria's. The conventional decision usually takes place by long term expectation. For that reason the profitability, liquidity of capital assets and margins of safety is most considerable factors. If we model Minsky's explanation of agent's behaviour, it will be as follows; convention $\rightarrow$ expectations $\rightarrow$ margins of safety.

\section{iii. Financial innovations}

A financial innovation is a capitalist dilemma. It brings flexibility in capitalist system as well as long term financial weakening. Minsky argued a financial innovation is the result of competitive pressures of capitalism to make profit (1986).He explained the banker and the entrepreneur both are the agent of profit seeking and does the financial innovation for the easiness of the business activities by bypassing the difficulties and barriers which are imposed and provisioned by regulatory body as well as natural economic system for the fulfilment of finance funding process.

\section{iv. IOU and its phenomenon}

In complex capitalist system most of the finance is occurred out of debt and securitisation. Minsky (1972) claimed that any economic unit can emit liabilities by securing general acceptance of them. The statement seems to be strange but it is true that in interdependence capitalist economic system banks and other monetary institutions willing to the acceptance of others IOUs by exchanging their own IOUs. The transferability is determined hierarchical in which central bank is on the top. In the process of expanded growth the hierarchical liquid assets come the presence in availability which deepening the layering of financial relationships. The framework is also similar to Austrian business cycle theory. The assets of bank come from the deposit of household's savings, business supply of acceptable assets, government as a state and other financial institutions.

The leveraging process works as follows by hierarchal;

-the borrower leveraging refers to meet the obligation of term and conditions of repayment.

-bank leverage refers to the capacity of fulfilling promise to the central bank and delivering their IOUs.

-the IOUs of central bank and government treasury depend upon collected taxes by the government other obligatory income. Minsky claimed the role of the reflux mechanism is directly related the weakening process of the financial structure. When there is no or less reflux the refinancing process is needed at the macroeconomic level to inflate the money or to a depreciation of money in international level. 


\section{v. Bankers role}

Minsky emphasised on banking system too much in capitalist system. Critics are sometimes criticized his theory as appropriate in single unit of economy. He claimed bankers as a source of dynamism as well as destabilization. He analysed banks as a contributor to all economic activities of financing and funding directly or indirectly. He detailed the layers of financing containing bank IOUs. He defined those institutions as a depository institution and other financial institution. Depository institutions deposits can be counted as it is properly defined and can access directly to central bank refinancing. But the other financial institutions haven't any accessibility to refinancing process of central bank. They need to be leveraged on commercial bank or to any other depository institutions. Both institutions are obtaining their incomes through arranging financing and service sale. He argued bank as the heart of capitalism who can promote both stability and instability. The fundamental role bank is evaluating the creditworthiness of the potential customers and borrowers. But in market oriented financing underwriters and analysts are playing the same role of loan officer but they have no continuous and long term relation with clients and bankers (Minsky, 1994). That's why Minsky suggest for proper structure of banking system. In opposite to the loan officer the operator of bankers is like sellers and act like underwriters. Their assumption as like anytime they are able in refinancing the position own by them with a low cost than the profitability of granting cost. He explained that banks promote speculative and ponzi finance because of two reasons; 1) their assets maturity period is shorter than the maturity of loan they granted. 2) For the maximisation of market share they encourage and give incentive for short term debts rather than long term debts.

\section{vi. External funds and its cost}

The cost of external fund is a crucial factor of Minsky model. The cost is incurred by buying and holding cost including wastage. The relationship between cash inflows and cash outflows are very essential Minsky's financial instability hypothesis. Normally financial cost includes debt services, store expenses, insurance cost and other cost of financial contract. But Minsky recognised it as improper financial cost estimation when the debts are in short term period. He gave important to the amortization of the principal. The expense of external fund also increases in case of higher interest rates, shorter maturity period, and other requirements. Value of collateral decreases also an extra pressure on external fund cost.

\section{vii. The cash flow analysis and the margin of safety}

To analyse the economic unit's capability Minsky suggested that it has to be sure about it enough cash inflow (CIF) generation to make sure cash balance (IB) to meet up the cash outflow (COF) and others financial commitment. According to him the economic unit need to be as follows;

$\mathrm{IB}+\mathrm{CIF} \geq \mathrm{COF}$ or

$\mathrm{IB}+\mathrm{NCF} \geq 0$ Where NCF refer to net cash inflow where there are no other availability of cash.

He claimed the economic unit try to generate money before compromising defaulting to meet the liquidity and to avoid losing reputation and good credit equivalent to worth of the unit. The entire situation he described as a cash box condition. He further explained the margin of safety of an economic unit without which the unit need to go for sale, shutdown and bankruptcy which is the final solution and instability situation for the economy. He depicted three scenarios of the margins of safety as follows;

The net cash inflow in positively on income and in the balance sheet formula as; cash flow margin= $\mathrm{E}$ $(\mathrm{NCFO})>0$.

Raise cash at low cost from portfolio operations formula as; portfolio margin or net worth margin= $\mathrm{E}$ (NCFp) $>0$.

Idle of superfluous liquid formula as; cash margin $=\mathrm{IB}>0$.

On the basis of cash box condition and margin of safety of an economic unit, Minsky innovate replace the business cycle by analysing hedge, speculative, ponzi financial situation.

\section{viii. Accumulation process}

Minsky preferred the equation of Kalecki of calculating aggregate profit for the determination of aggregate income. The characteristic of the equation refers to the expense and income approaches to the GDP. The assumed behavioural and causal assumptions transform the GDP identity into equality. The equation explanation is as below;

$\prod=\mathrm{I}+(\mathrm{G}-\mathrm{T})+(\mathrm{X}-\mathrm{J})+\mathrm{C} \Pi-\mathrm{Sw}$

In the above $\prod$ is not controlled by any economic agent. But the I(investment expenditures), $G$ (public expenditures), X(exports), J(imports), CП(consumption) and Sw-worker's savings out of worker are derived from the decision process. I and $\mathrm{G}$ seems to be the leading variables in an economy and the opposite and adverse situation of economy can be control by using the aggregate public expenditures. But the risk comes from the 
expected increase of external fund. Because increased external fund comes with the increased ratio of debt and equity. The increased debt equity ratio further influence the perceived risk even sometimes it may not found.

\section{ix. The financing and funding process}

Minsky (1990) classified all the economic activities into two different categories; the production of assets and carrying of assets. Carrying of assets includes the process of acquire the position and maintain which are already have. Both of the activities are supported by the financing and funding process which Minsky called flux and reflux. Flux of money refers to the process how money is created and the reflux refers to the expanding and borrowing the savings which is existing as a liquid. Rollover, renegotiation, consolidation of existing contract which Minsky called the refinancing activities also is a vital part of funding process. He analysed all type of economic agents need financing and except the authority of issuing IOUs needs to be refinancing. All the economic agents need for financing because their IOUs have to be accepted for their implementation of economic decision.

\section{x. Fragility v/s instability}

Those words are frequently used by Minsky. The critics sometimes said it as vague to define. Though the financial fragility and instability is meant more or less similar, he explained fragility as an over indebtedness. He analyzed financial fragility is built-in in an economic system. It's a process and come round with the rapid growth of any economic sector. He analysed his business cycle by showing how fragility is works.

\section{xi. Phenomenon of boom period}

Minsky much emphasised on the role of boom period. He mentioned it as a short term but very important to know its phenomenon when it leads to closely full employment and optimism. This period is critical and makes ever more demanding liability structure focusing on prospective yield. He agreed with Keynes and Marx that economic yield comes from technological development and squeezing workers real wages. Economic boom brings inflationary barrier and Minsky argued if it unchecked than it leads to a deep crisis. He mentioned some unproductive economic activities happen in boom period like takeover, merger and conglomerate expansions. The period also includes household's willingness to use more debt and take more risk to cash commitment though their incomes haven't increased.

\section{xii. Financial structure and effectivity}

Traditionally it is called by mainstream economics and neo-classical economics that the open market or free economy doesn't comes with the full employment by nature and its characteristics but government needs to promote the full employment. Minsky explained the boom phenomenon created from out of full employment $\mathrm{He}$ claimed that $1^{\text {st }}$, strong financial structure and effective policy can prevent the moral hazard of profit orientation, $2^{\text {nd }}$, full employment orientation is the best policy rather than growth orientation by anyhow, $3^{\text {rd }}$, it is very difficult to cope with the inflation within the fragile financial situation. So he suggested for socialization of investment and refinance for the weaken sector for development and be innovate if it can't improve central authority should let them go and concentred to other sectors for the betterment of the economy.

\section{Xiii. Managerial capitalism v/s money managerial capitalism}

The above findings Minsky is a great addition to the economic analysis. Though the concept is not in Minsky's framework without this idea it will be tough to know about the trend of capitalism. He basically had done analysis on capitalism in short-term basis. But he analysed the long term capitalism characteristics as well. $\mathrm{He}$ argued the capitalist economy gone through a series of cycle named by commercial, financial, managerial and the present continuing era is money managerial capitalism. The scenario comes from the deregulation and the concept of globalisation. Mobility of external fund reduced the capability of managerial capitalism to keep control over economy.

\section{IV.III Minsky moment and evaluation of current credit crunch}

Minsky moment is an economic situation where ponzi finance dominates the market. According to Minsky theoretical framework, in this situation the borrowers can't meet the finance commitment. They can't payback the principal as well as the interest. He argued it happen when the market can't work effectively and moral hazard like profit orientation direct the economic agent to the optimism over reality. The higher authority's (central bank) imperfection is also liable for the situation. When Minsky moment takes place then too much economic pressure squeeze the public expenditure. The investors become too cautious to lend and the regulatory body also become strict in lending policy. The economic agents try anyhow to meet the finance 
commitment and in the final stage sales, shutdown and bankruptcy take place as a final solution. If we look at to the present credit crunch scenarios, we see all the symptoms described by Minsky are correct.

\section{IV.IV Business cycle and FIH}

Traditional and neo-classical mainstream economist analysed the business and economy comparing to human life where there are birth, growth, maturity and fall. The most influential views was smithian where full employment is assumed at all economic stages and it is believed economic shock comes from external environment, the second view is Keynesian view where it is believed that boom and busts, ups and down is the internal dynamics of economy and instability is the genuine social problem associated with the increasing of involuntary unemployment. The both smithian real business cycle theory and Keynesian business cycle theory proved inadequate in the last few recession periods. In this situation Minsky comes with a new theological framework called by financial instability hypothesis (FIH) in his book John Maynard Keynes in 1975. Minsky who supposed to say himself Keynesian claimed the boom and bust is built-in in capitalism and comes up through a specific economic agent. As an example new millennium dot.com bubble and the recent housing bubble. In his theory he innovate a new cycle of economy comprise with three financial situation hedge, speculative and ponzi finance. According to him effective market and central bank policy can mitigate and sustained the economic booming situation longer but new innovation, deregulation and changing in future expectation causing by rising in external fund, it is inevitable to resist the bust. Minsky supposed to be called the third horseman of the economy for his practical theory (Demian Perry, 2009). He replaced the business and economic cycle in different way but has proved the validity of business cycle. He claimed the bank as the hedge finance unit and following new financial innovation go for speculative and ponzi finance in the way of boom proceeds.

\section{IV.V Marx, Keynes and Minsky}

Economic development is a contentious process. It is the basic of human civilization. Economy is not created independently; it is the outcomes of human combined activity. That's why we see the complexity of human life is followed by the economic complexity. In the phases of era, there are so many social scientists and economist devotes their work to mitigate the socio-economic crisis and demand. The above three economist was the greatest. As with the changes of time the problem and phenomenon of problem also changed, the economist work also become inadequate. The new situation comes with new phenomenon requiring new measure. Minsky, the research subject of the researcher called as economist out of the mainstream. He said himself as a Keynesian and used to work with as an assistant of Alvin Hansen in Harvard who recognised as the American leading Keynesian. But Minsky's analysis is created from the Marx perspective. Minsky studied and analysed the short term economic instability through accumulation of wealth with the basis of Keynes article "the general theory of employment.

The Marxist used to emphasis on real sector as a tool of instability. But Minsky gave more emphasis on financial market. The critics of Minsky tried to say his hypothesis is appropriate for single unit only as he didn't emphasis on real sector which is called as a semiautonomous sector. As an evident, Minsky's hypothesis is not adequate to explain the 70 s and 80 s crisis. His theory of investment spending depend on expected rate of profit return exceeds the cost of capital. The Marxian's view is to change the society by take over the ruling authority from capitalist to working class where Minsky tried for establish and expansion of capitalism. The concept and perception of class conflict in Marxian thought is totally absent from Minsky and Keynes thought the way of economic thought development all of them are complimentary.

\section{IV.VI Minsky moment and mass psychology}

Minsky moment is an economic situation which was not termed by Minsky himself. It was termed by a researcher of PIMCO named by Paul McCulley in 1998 when he had been doing a research on Russian financial crisis. He clarified that the Minsky moment comes into being after the period of rapid growth and prosperity in the economic system with increased values of investment. The increased amount fuel to the speculation of the borrowing money and borrower can't repay the principal which followed by ponzi finance that occurred the Minsky moment. In the ponzi finance both of the interest and principal remain unpaid. He argued Minsky moment is a situation in the business cycle when the investors fall in cash flow problems for the reason of spiralling debt by the speculative finance. Magnus (2007), analysed the Minsky moment comes after a period of rapid debt acceleration. In this period borrowers have to borrow money for repay the existing loans. He defined the moment come when lenders become cautious and restrictive to lend because of inability to repay and assets price drop sharply which can't able to meet the securitization value. McCulley (2007) claimed if it becomes unchecked then it becomes Minsky meltdown which we can call recession as well. 


\section{IV.VII Government responses to Minsky framework}

Government is a political institution and the highest authority of a state. Its responsibility includes all the socio-economical aspect. As Minsky called by the capitalist economist, the basic process of capitalist government is so called democracy (by the people, of the people and for the people). But the fundamentals of capitalism are to make profit. So the practitioner of the political institution is always in dilemma. They can't predict, direct or be decisive like natural scientist. The phenomenon of government and their concept and status also influential factors like religious country, developing country, developed country, underdeveloped country and economically dependant country. The researcher likes to say it as a poli-psychological factor. That's why we see in developed countries a large amount of bail-out has declared for the financial institutions whereas some countries demanding help internationally for recovery.

\section{IV.VIII Advance sense of new era}

Hyman Minsky in his FIH gave attention on economic short term instability. The research is conveying his complete hypothesis of short term economic cycle of capitalism. But he argued that the situation phenomenon is changing with the phases of time. That's why he also was interested in the long term evaluation of capitalism. According to Minsky (1990,1993), US economy (which is representing the capitalist authority) had passed at least three phases of economy which Minsky named as commercial capitalism, financial capitalism, managerial capitalism which are followed by entering in a another phase of capitalism in 1980s which he called money manager capitalism. He analysed in commercial capitalism the state was most powerful to control the socio-economic situation but in early nineteenth century the financial sectors was the critical determinant for the policy making. But after great depression the corporate managerial policy take place to control over the financial portfolio. From the 1980s the financial deregulation, globalization and labour mobility are the forces to weaken the managerial capitalism and increasing the interdependency. That's why we se the framework of Adam Smith and Keynes is inadequate to explain the recent financial crisis.

\section{Conclusions and Recommendations}

The economic crises are a result of rapid boom proceeding to bust and the inappropriate policies taking by government of a state. This problem can be seen differently according to socio-psychological perspective of the people how we look at it, poli-psychological perspective what steps they take and how they feel it compare to others. The research is too bust that's why the researchers have gone to focus on Hyman P. Minsky's hypothesis and its validity to the current economic situation.

The actual and viewed impact of credit crunch is different. It's also different depending on different classes. As most of the research is conducted by the business and upper class interest group so it is impossible to know the actual feature of the under poverty line people. Because economy work only to the people who have the ability and wish to fulfil one's demand. But we see state and the public institutions declared lot of money rescuing the companies and largest institution.

Hyman Minsky's hypothesis is playing an important role to the analysis of present capitalist economy. The research problem is on the current financial crisis but his framework and hypothesis is most appropriate and updated that's why we see his work is reviewed by and studying vastly. His hypothesis is based on investment followed by future expectation and the cost of external fund is a considerable factor. His argument about the instability is the process of capitalism within in which boom is followed by bust. His short term analysis is carrying the appropriation to analyse the present financial crisis and his long term analysis is conveying the predictive feature of the capitalism. His intention was to find out the process of instability of capitalism and looking for how to make sure the prosperity and stability of the system. He talked about the effectivity of government via central bank focusing on full employment not to the growth. But the politicians are looking for the quick recovery by fuelling the boom again putting more and more incentives for the voting issues. They are trying to manage the inflation by making more inflation.

The most critical tools of capitalism are money, commercial papers and IOU. The inflation is the creation of money management system. Circulation of money in modern banking system makes the money 99 times more than the real. The extra money comes from the IOU and government guarantee. Following the supply and demand curve when the more money is available in market the value of market deflated at the end. So we see the product price and living expense going up in the phases of time. But we analyse it clearly then we can see the matter is comes from the devaluation of the money. The IOU and government guarantee by promissory notes, bond, stock and others assurance is one kind of debt. The debt followed by extra needs of money which comes from the more debt. And the process is going on what Minsky explain the financial crises is built-in in the capitalism within.

The business and economy now a day is integrated and makes the world under a roof. The continuous innovation of financial tools and business concepts is making hard for the state authority to keep control. The Minsky sensed it and define it as a turning of managerial capitalism to money manager capitalism. According to 
him the phases of long term economy cycle is changing with the unpredictive financial innovation. He analysed, it is happening with the expansion of capitalism itself and every phase obviously comes with new situation requiring new policy and solutions. He explained that the bank and financial deregulations have opened the door of new era. He claimed that the financial crises now a day can't be solved by the single state. The sustainability of an economy depends on full employment but the bond, merger, mobility of money and labour is strong forces to keep in control. That's why Minsky suggested financial crisis required co-operative responsibility by the all parties and state of the world.

We are seeing his framework is followed by the world and creating joint group and organisation internationally. IMF, G-8, G20, World Bank is the creation out of similar concept. But what Adam smith argued in the primitive stage of economy theory development that the tradesman influence the role of corporate strategy of the state authority and corrupt the economy. In open market policy, all the investors targeting cost efficiency as a competing tools. But the efficiency mostly comes from the decreasing wages and technological development which also liable for unemployment. What Minsky argued as a capitalist economist is also said by previous orthodox and mainstream economist like Adam smith, Keynes, Marx that unemployment is the main source of economic instability. The source of unemployment is created from tradesman policy of efficiency and maximisation of profit. If we develop the concept in current situation than we can say the tradesman policy of efficiency and profit maximisation if followed by the least risk investment and the financial sectors is the best ground for them. We see financial institutions became loser but the directors become wealthy. They are creating money out of debt, doing business with others money and getting profit to their pocket. Minsky sensed it from the process of profit and fund accumulation.

The complexity is coming in front how to manage money. The issue of full employment and growth is vital for the state. But the state policies can't keep pace with situation as the wave of money matter includes the entire world in together. With the large disposable income countries are the least affected from the financial crisis like India, china, Japan and Korea. So how it comes that the richest countries are affecting more from the financial crisis? The answer could be like, their disposable income is less or the high growth doesn't represent the balanced in the income of different classes in population. We saw millions of peoples became jobless in US and UK. Greece became insolvent as a state. But they are the authority of capitalism. They are trying to save money by cutting budget from public and social welfare and putting money to rescue the financial institutions proved as a most liable for the current situation. They are trying to inflating the economy by supplying more money which will follow another crisis in a regular process of capitalism. So we have to be cautious about the poli-psychology. We need the positive eco-system in the society where everybody will feel a member of a family. The money market will be socio and people oriented rather than profit oriented. We need to know as a state or any authority, profit orientation are bringing the war and epidemic. It makes the capitalist irresponsible to the society and environment which going to bring the result of disaster. Karl Marx gave a solution by revolution and taking power by the working class who will keep the balance in society and will bring the full employment. But the process is needed to be reviewed by the way Minsky thought in the perspective of Marx. Because the society has gone too far and the advanced capitalism entered into the new era. The colonisation process of managerial capitalism have been replacing by money managerial capitalism. The money accumulation process is creating the international tension. So we see the war madness costing lot of lives and taxpayer money wherein taxpayers dying from unavailability of fundamental needs and natural disaster.

So researcher likes to say the poli-psychology has to be clarified and mass people based. The government of a state must need to full employment oriented and basic needs have to be ease accessed. The money should be managed carefully by minimizing the income and economic class differences. For the purpose of money management green bank concept should bring forward in which the rolling money by modern banking circulation process will not more than the real money and the creation of money out of debt will be less or eliminated. The accumulation of external fund needs to be monitored and controlled. The open market concept needs to be reviewed. The mobility of money is easy than the mobility of labour. The ease mobilization of labour is creating brain drainage. So if the money market becomes integrated must have to be followed by the integration of labour market. Without a fair and strict integrated policy, non-corrupted tradesmen's and polipsychology, the above problem can't be minimized for the long run.

\section{References:}

[1]. Adam smith, 1776, "Of the wages and profit in the different employments of labour and stock", An Inquiry into the Nature and Causes of the Wealth of Nations. Book 1, Chapter 10. Online available at , http://geolib.com/smith.adam/won1-10.html

[2]. Baker, Dean(2009), "Geither's plan will tax main street to make Wall Street richer," The HuffingtonPost. Online available at, http://www.huffingtonpost.com/dean-baker/geithners-plan-will-taxm_b_181021.html

[3]. Benston, G. J., and G.G., Kaufman (1995), "Is the banking and payments system fragile?" Journal of Financial Services Research. Online available at,

[4]. http://www.springerlink.com/content/q304701t253q2324/

[5]. Bernanke, B. S., (1983), "Non-monetary effects of the financial crisis in the propagation of the Great Depression." American Economic review. Online available at, http://www.nber.org/papers/w1054.pdf 
[6]. Buffett, Warren E., (2008), "Letter to shareholders", Berkshire Hathaway Inc., 2007 Annual Report. Online available at, http://www.berkshirehathaway.com/letters/2007ltr.pdf

[7]. Daniela Travasci and Jan Toporowski, (2009), "Minsky, Financial Development and Crisis." Palgrave, forthcoming. In Charles J. Whalen (2009), (eds.), "A Minsky Perspective on the Global Recession." Online available at, http://faculty.buffalostate.edu/joth/pk2009/Site/program files/whalen.pdf

[8]. dailyrecord.co.uk (Sep 16 2009) "Number of unemployed in UK hits highest figure since 1995 at $2.47 \mathrm{~m}$ ". online available at http://www.dailyrecord.co.uk/news/uk-world-news/2009/09/16/number-of-unemployed-in-uk-hits-highest-figure-since-1995$86908-21677113 /$

[9]. Demian Perry (2009), "Minsky Moment: the 'third horseman' of the economy" online available at, http://monsterhash.com/beta/2009/exclusives/money/financial-instabilty-hypothesis-the-forgotten-economic-theory/

[10]. Der Hovanesian, Mara (2006), "Nightmare mortgages," Business Week. Online available http://www.businessweek.com/magazine/content/06_37/b4000001.htm

[11]. discusseconomics.com (June 3 2009) "12.5 million unemployed in the united states" online available at, http://www.discusseconomics.com/macroeconomics/125-million-unemployed-in-the-united-states/

[12]. Dymski, Gary and Robert Pollin (1992), 'Minsky as hedgehog: the power of the Wall Street paradigm,' in Steven Fazzari and Dimitri B. Papadimitriou (eds.), Financial Conditions and Macroeconomic Performance: Essays in Honour of Hyman P. Minsky, Armonk, New York: M.E. Sharpe, pp. 27-61.Online available at, http://papers.ssrn.com/sol3/papers.cfm?abstract_id=184760

[13]. Ferri, P. and H.P. Minsky (1992), Market Processes and Thwarting Systems.

[14]. Structural Change and Economic Dynamics 3, 1: 79-91. In Eric Tymoigne (2006), (eds), "properties of the Minskyan analysis and how to theorize and model a monetary production economy." The Minskyan System, Part 1. Working paper no.452, UMKCdepartment of economics. Online available on http://www.levy.org/pubs/wp_452.pdf

[15]. Galbraith, James K., (2009), "The Geithner's plan won't work," The Daily Beast. Online available at, http://www.thedailybeast.com/blogs-and-stories/2009-03-24/the-geithner-plan-wontwork/full/

[16]. Glover, Robert W. and Christopher T. King (2010), 'Sectoral approaches to workforce development: toward an effective U .S. labour market policy,' in Charles J. Whalen (ed.), Human Resource Economics and Public Policy: Essays in Honour of Vernon M. Briggs Jr., online available at, http://www.upjohn.org/publications/ch1/hrepp.pdf

[17]. Krugman, Paul (2009), 'Despair over financial policy,' The New York Times. Online available at,http://krugman.blogs.nytimes.com/2009/03/21/despair-over-financial-policy/

[18]. Krugman, Paul (2009), 'Geithner plan arithmetic,' The New York Times. Online available at,

[19]. http://krugman.blogs.nytimes.com/2009/03/23/geithner-plan-arithmetic/

[20]. Lahart, J. (2007), In Time of Tumult, Obscure Economist Gains Currency. The Wall Street Journal (August 18): 1. Online available at http://online.wsj.com/article/SB118736585456901047.html

[21]. Langfitt, F. (2007), Job Cuts a Symptom of Struggling Economy. All Things Considered, National Public Radio (September 7). Online available at, http://www.npr.org/templates/story/story.php?storyId=100804782

[22]. Magnus, G. (2007), The Credit Cycle and Liquidity: Have We Arrived at a Minsky Moment? Economic Insights-By George. UBS Investment Research, London. Online available http://www.publicradio.org/columns/marketplace/farrell/George\%20Magnus\%20020707.pdf

[23]. Markus k. B, 2008, "Deciphering the liquidity and credit crunch", 2007-2008.

[24]. Online available at, http://www.britannica.com/bps/additionalcontent/18/36434808/Deciphering-the-Liquidity-and-Credit-Crunch2007\% C3\%84\%C3\%AC2008 (visited on Dec 25, 2009.)

[25]. Marx, Karl (1981) Capital, vol. 3. New York: Random House (Vintage Books). Online available at, http://books.google.co.uk/books?id=rA66GMF7aHYC\&pg=PA326\&dq=Marx,+Karl+(1981)+Capital,+vol.+3.+New+York:+Rando $\mathrm{m}+$ House+(Vintage+Books).

[26]. Marshall, Ray (2010), 'Learning systems for a globalized economy: do Americans face tough choices or tough times?' in Charles J. Whalen (ed.), Human Resource Economics and Public Policy: Essays in Honour of Vernon M. Briggs Jr., Kalamazoo, Michigan: W.E. Upjohn Institute for Employment Research, forthcoming. Online available at, http://www.upjohn.org/publications/ch1/hrepp.pdf

[27]. Minsky, H.P., (1964). "Financial crisis, financial system and the performance of the economy." In Private Capital Markets, ed. Commission on Money and Credit, 173-380. Englewood Cliffs: Prentice-Hall. In Eric Tymoigne (2006), (eds), "properties of the Minskyan analysis and how to theorize and mocel a monetary production economy." The Minskyan System, Part 1. working paper no.452, UMKC-department of economics. Online available on http://www.levy.org/pubs/wp_452.pdf

[28]. Minsky H.P., 1972, “An evaluation of recent monetary policy.” Nebraska Journal of Economics And Business 11 (4): 37-56.

[29]. Minsky H.P., 1975a, "Suggestion for a cash flow-oriented bank examination." Proceedings of a Conference on Bank Structure and Competition. Chicago: Federal Reserve Bank of Chicago.

[30]. Minsky, H.P. (1975b), "John Maynard Keynes". New York: Columbia University Press. "Can 'It' Happen Again?" Essays on Instability and Finance,Armonk, NY: Sharpe, 1982. In Charles J. Whalen, 2008. (eds), "The credit crunch: A Minsky Moment." Studiee note di economis. Anno X111, n.1-2008. Page ( 3-21) . Online available at, http://www.mps.it/NR/rdonlyres/D27537E2FE99-4675-BC4E-9186DF4B924B/28637/Whalen.pdf

[31]. Minsky, H.P., 1983, "Pitfalls due to financial fragility." In Weintraub, S. and M. Goodstein (eds.) Reaganomics in the Stagflation Economy. Philadelphia: University of Pennsylvania Press.

[32]. Minsky, H.P., 1986, Stabilizing an Unstable Economy, New Haven, CT: Yale University Press . Online available at, http://www.scribd.com/doc/11626149/Minsky-Stabilizing-an-Unstable-Economy-Complete

[33]. Minsky, H.P 1989. "Comments and discussions." Brookings Papers on Economic Activity, 2: 173-189. In Eric Tymoigne (2006), (eds), "properties of the Minskyan analysis and how to theorize and mocel a monetary production economy." The Minskyan System, Part 1. working paper no.452, UMKC-department of economics. Online available on http://www.levy.org/pubs/wp_452.pdf

[34]. Minsky, H.P., (1990a), 'Schumpeter: finance and evolution,' in Arnold Heertje and Mark Perlman (eds.), Evolving Market Technology and Market Structure: Studies in Schumpeterian Economics, Ann Arbor: The University of Michigan Press, pp. 51-74. In Charles J. Whalen, 2008.(eds), "The credit crunch: A Minsky Moment." Studiee note di economis. Anno X111,n.1-2008. page( 3-21). Online available at, http://www.mps.it/NR/rdonlyres/D27537E2-FE99-4675-BC4E-9186DF4B924B/28637/Whalen.pdf

[35]. Minsky H.P., 1990b, "Money manager capitalism, fiscal independence and international monetary reconstruction." In SzabóPelsöczi, M. (ed.) "The Future of the Global Economic and Monetary System". Budapest: Institute for World Economics of the Hungarian Academy of Sciences. 
[36]. Minsky H. P (1992), The Financial Instability Hypothesis. The Jerome Levy Economics Institute Working Paper No. 74. Bard College, Annandale-on-Hudson, New York. Online available at,

[37]. http://devpapers.ssrn.com/sol3/papers.cfm?abstract_id=161024

[38]. Minsky H.P., 1993, “On the non-neutrality of money.” Federal Reserve Bank of New York Quarterly Review, 18 (1): 77-82.

[39]. Minsky H.P., 1994, "Financial instability and the decline (?) Of banking public policy Implications." In Proceedings of a Conference on Bank Structure and Competition. Chicago: Federal Reserve Bank of Chicago

[40]. Minsky, H.P., (1995), 'Longer waves in financial relations: financial factors in the more severe depressions II,' Journal of Economic Issues 29 (1), 83-95. In Charles J. Whalen (2009), (eds.), “A Minsky Perspective on the Global Recession." Online available at, http://faculty.buffalostate.edu/joth/pk2009/Site/program_files/whalen.pdf

[41]. Minsky, Hyman P. and Charles J. Whalen (1996-97), 'Economic insecurity and the institutional prerequisites for successful capitalism,' Journal of Post Keynesian Economics 19 (2), 155-170. 'Minsky's moment' (2009), Economist.com. http://www.economist.com/finance/displaystory.cfm?story_id=13415233

[42]. Mitchel Y. Abolafia (2009) "Can Speculative Bubbles Be Managed? An Institutional Approach". Online available at, http://www.pmranet.org/conferences/OSU2009/papers/Abolafia,\%20Mitchel\%20Y.\%20Can\%20Speculative\%20Bubbles\%20be\%2 0Managed\%20-\%20An\%20Institutional\%20Approach.pdf

[43]. Noam Chomsky (2006). "Failed States:The Abuse of Power and the Assault on Democracy" Metropolitan Books- Henry Holt \& Co. Paul McCulley, 1998, "1998 Russian financial crises", PIMCO. Online available at http://www.finance.reachinformation.com/Minsky_moment.aspx visited on Dec 3,2009.

[44]. Roger W. Garrison, (1997). "The Austrian Theory of the Business Cycle" review on David Glasner, ed., Business Cycles and Depressions,New York: Garland Publishing Co., 1997, pp. 23-27 online available at, http://www.auburn.edu/ garriro/a1abc.htm

[45]. RT Clair and P. Tucker (1993), "six causes of the credit crunch" economic review-third quarter 1993, federal reserve bank of Dallas. Online available at, http://www.dallasfed.com/research/er/1993/er9303a.pdf

[46]. Stephen lendman (2007) "market efficiency hokum". Online available at, http://www.rense.com/general78/makr.htm

[47]. Stiglitz, Joseph E. (2009) 'Obama's ersatz capitalism,' The New York Times. Online available at, http://www.nytimes.com/2009/04/01/opinion/01stiglitz.html

[48]. Stuart Calder, 2008, "How technology will change the way we invest, Beyond the credit crunch", Product Director, Northern Europe, Linedata Services. Online available at, http://www.thehedgefundjournal.com/special-reports/technology-insight2008/beyond-the-credit-crunch.php

[49]. Telegraph.co.uk (2009), "Bank of England holds interest rates at $0.5 \mathrm{pc}$ ". Online available at, http://www.telegraph.co.uk/finance/economics/interestrates/6167245/Bank-of-England-holds-interest-rates-at-0.5pc.html

[50]. Themoneystop.co.uk (2009) "Global financial job losses to be huge". Online available at, http://www.themoneystop.co.uk/012009/global-financial-job-losses-to-be-huge.html

[51]. Tobin, J. 1989. Review of Stabilizing an Unstable Economy by Hyman P. Minsky. Journal of Economic Literature 27(1): 105-108.

[52]. Whalen, Charles J. and Jeffrey Wenger (2002), 'Destabilizing an Unstable Economy,' Challenge 45 (6), 70-92. Online available at, http://www.questia.com/googleScholar.qst;jsessionid=LHJZwHybGGT0rYRjXBVkzPJjJ7RTVYXrZY23vQz07N1mvmQ1GvbL!$165273011 ! 1581092936 ?$ docId $=5000641170$

[53]. WHALEN, C.J. (2008) “The Credit Crunch: A Minsky Moment” Studi e Note Di Economia Anno XIII, n. 1-2008, page. 03-21. online available at, http://www.mps.it/NR/rdonlyres/D27537E2-FE99-4675-BC4E-9186DF4B924B/28637/Whalen.pdf 